TAPROBANICA, ISSN 1800-427X. January, 2015. Vol. 07, No. 01: pp. 43-44.

(C) Research Center for Climate Change, University of Indonesia, Depok, Indonesia \& Taprobanica Private Limited, Homagama, Sri Lanka www.taprobanica.org

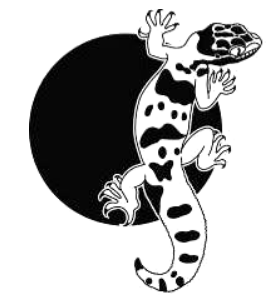

\section{Rediscovery of two Darts (Lepidoptera) in Sri Lanka after 90 years}

A total of 245 butterfly species (Order Lepidoptera: Papilionoidea) have been recorded from Sri Lanka (d'Abrera, 1998; Van der Poorten, 2012). Although a listing of 245 species is substantial not all species are common, some may be widespread and uncommon. In particular, Potanthus [Hesperiidae] is widespread geographically with three species occurring in Sri Lanka: $P$. pallida, $P$. confucius and $P$. pseudomaesa. According to a recent publication (Jayasinghe, 2013), P. pallida and P. pseudomaesa are rare in Sri Lanka.

In $1924 \mathrm{~W}$. Ormiston observed P. pallida (Indian Dart) and P. pseudomaesa (Common Dart) in Sri Lanka and this record was included in Woodhouse (1942). Since 1924, 90 years later, there have been no records of $P$. pallida and $P$. pseudomaesa in Sri Lanka.

The species of Sri Lankan Potanthus exhibit very subtle diagnostic traits. According to Ormiston (1924) $P$. confucius and $P$. pseudomaesa are orange in colour and have a different arrangement of spots on the dorsal surface of the wing, $P$. pallida is very similar to $P$. pseudomaesa and the female of $P$. pallida closely resembles the female of $P$. pseudomaesa on the dorsal surface of the wing. Ormiston (1924) provided the following diagnosis for $P$. pallida: "The yellow band is very narrow, and the spots in cell 4 and cell 5 are well separated from both the discal and apical series. There is a spot in cell 7, but none in cell 6 . The band on the hindwing is not divided by brown lines. The male has the yellow markings greatly reduced, and the band on the hind wing is broken up by brown lines along the veins. The under-side of the hindwing in both sexes has a distinctive greenish tinge".
On the other hand P. pseudomaesa is a large form in comparison to $P$. pallida and $P$. confucius. Furthermore, $P$. pseudomaesa shows "The yellow band on the forewing is broken, the spots in cells 4 and 5 are not joined to the apical group, but usually to the discal cell in the male, on the lower (hind) wing the band is divided along the veins by brown lines. There is, as a rule, a small well-defined spot in 6 , and sometimes a larger faint and diffuse one in cell 7. It varies much in size. In cell 9 the yellow markings are much reduced, and the band on the forewing is more broken, the spots in cells 4 and 5 being almost invariably well separated from both the apical and discal series. On the ventral surface there is usually a very minute spot in 6" (Ormiston, 1924).

During field visits from 2012 to 2014, we discovered and photographed $P$. pallida (Figs. $1 \& 2$ ) and $P$. pseudomaesa (Figs. 3 \& 4) providing the records of these species in Sri Lanka after a period of 90 years. These are also the first photographs of live specimens for these two species in Sri Lanka. We observed a single individual of $P$. pallida in each of two locations in Sri Lanka. The first observation occurred at the middle of the "Paraviyangala" mountain in Badulla District $\left(6.737400^{\circ} \mathrm{N}\right.$, $80.794365^{\circ} \mathrm{E}, 1158 \mathrm{~m}$ ) on 14 October 2012 at 14:38. The observation was made on a sunny day and in a natural open grassland area. Our second observation was at "Bambarakanda" mountain road in Ratnapura District $\left(6^{\circ} 46^{\prime} 15.40^{\prime \prime} \mathrm{N}, 80^{\circ} 50^{\prime} 6.32^{\prime \prime} \mathrm{E}, 1076 \mathrm{~m}\right)$ on 07 July, 2014. The individual was similarly observed on a sunny day at 10:24 in a disturbed open area. More recently we observed six individuals of $P$. pseudomaesa at the "Dothalugala Nature Trail - Knuckles Mountain Range" in Kandy District $\left(7.336272^{\circ} \mathrm{N}, 80.856397^{\circ} \mathrm{E} ; 1175 \mathrm{~m}\right)$ on 14 June, 2014, at 08:12. This observation occurred on a sunny day and in a natural open grassland area. 


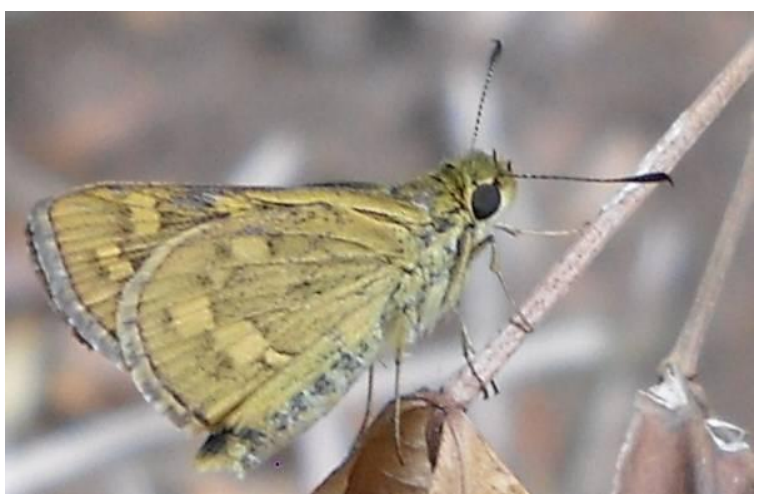

Figure 1: ventral wing surface of female $P$. pallida

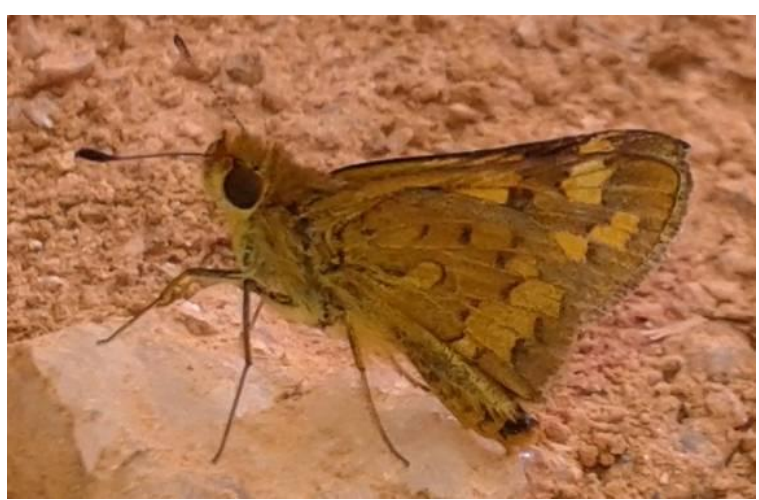

Figure 2: ventral wing surface of male $P$. pallida

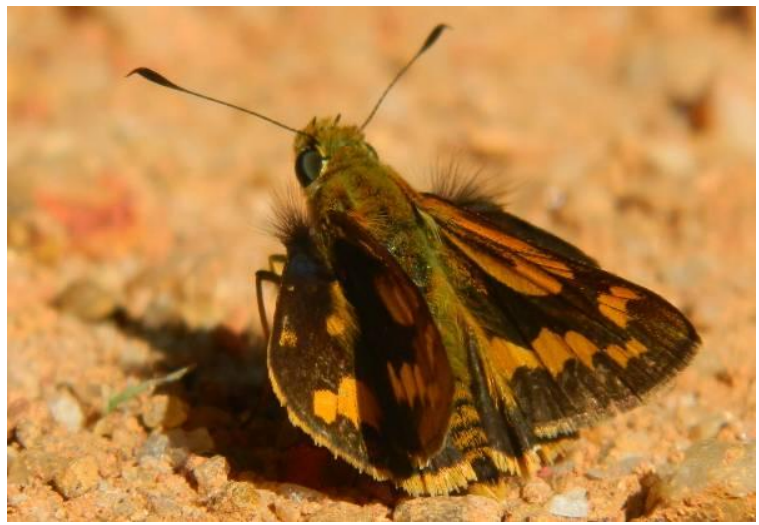

Figure 3: dorsal wing surface of male $P$. pseudomaesa

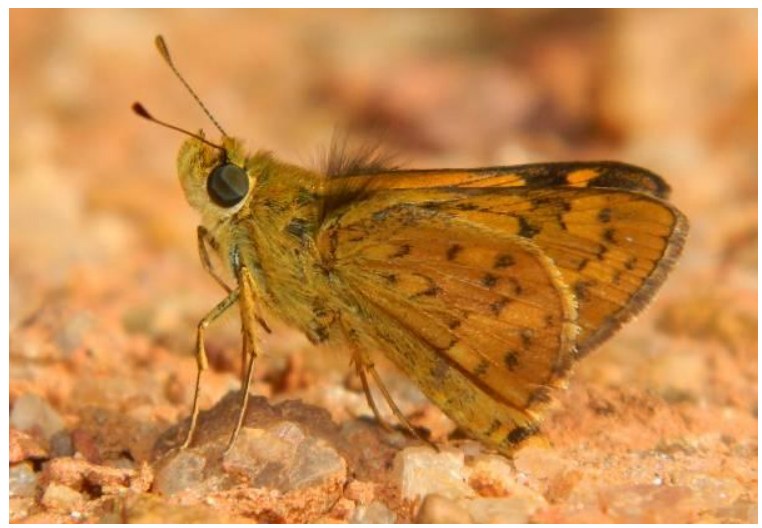

Figure 4: ventral wing surface of male $P$. pseudomaesa

\section{Acknowledgements}

We wish to thank Sunny Chir (Butterfly specialist and photographer, Singapore), T. L. Seow (Member of the Butterfly Circle, Malaysia), Kanishka D. B. Ukuwela (University of Adelaide, Australia) and Himesh Jayasinghe (Butterfly Conservation Society of Sri Lanka) for assistance and support.

\section{Literature Cited}

d'Abrera, B., 1998. The Butterflies of Ceylon. Wildlife Heritage Trust of Sri Lanka, Colombo: 203.

Ormiston, W., 1924. The Butterflies of Ceylon. H. W. Cave \& Co., Colombo.

Van der Poorten, G., 2012. The Taxonomy and Conservation Status of the Butterflies of Sri Lanka. In: Weerakoon, D. K. and S. Wijesundara (eds). The National Red List 2012 of Sri Lanka; Conservation Status of the Fauna and Flora. Ministry of Environment, Colombo, Sri Lanka: 26-41.

Woodhouse, L.G.O., 1950. The Butterfly Fauna of Ceylon. Second (Abridged) Edition. Colombo: Ceylon Government Press: 209.

Jayasinghe, H., C. De. Alwis, and S. S. Rajapakshe, 2013. A Pocket Guide to the Butterflies of Sri Lanka. First published, Homagama: 55.

Submitted: 29 Aug. 2014, Accepted: 10 Oct. 2014 Section Editor: Jeffrey Miller

T.M.T.S. Priyadarshana ${ }^{1}$, C. de Alwis ${ }^{1} \&$ G.V.I.H. Wijewardana ${ }^{2}$

\footnotetext{
${ }^{1}$ Department of Natural Resources, Faculty of Applied Sciences, Sabaragamuwa University of Sri Lanka, Pabahinna 70140, Sri Lanka E-mail: tharakas.priyadarshana@gmail.com

${ }^{2}$ Sri Lanka Schools of Agriculture, Karapincha, Kuruwita, Sri Lanka
} 